\title{
PENGARUH PARITAS TERHADAP BBLR DAN PREMATUR DI RS MUHAMMADIYAH PALEMBANG 2019
}

\author{
Reni Saswita \\ Dosen Program Studi DIII Kebidanan STIKES Mitra Adiguna Palembang \\ Komplek Kenten Permai Blok J 9-12 Bukit Sangkal Palembang 30114 \\ Email : rswita@gmail.com
}

\begin{abstract}
Abstrak
Paritas merupakan faktor yang sangat berpengaruh terhadap hasil konsepsi. Paritas yang tinggi akan berdampak pada timbulnya berbagai masalah kesehatan baik bagi ibu maupun bayi yang dilahirkan. Paritas mempengaruhi hasil luaran bayi antara lain kejadian afsiksia, BBLR dan prematur. Penelitian ini bertujuan untuk mengetahui hubungan antara paritas dengan hasil luaran bayi di Rumah Sakit Muhammadiyah Palembang yaitu BBLR dan prematur. Penelitian ini adalah jenis deskriptif analitik dengan rancangan retrospektif terhadap 336 sampel. Populasi pada penelitian ini adalah semua bayi baru lahir yang tercatat di rekam medis $R S$, sampel penelitian berjumlah 336. Analisis penelitian dengan menggunakan analisis chi square. Hasil penelitian menunjukkan ada hubungan antara paritas dan BBLR p value $(0,006>0,05)$ dan dan ada hubungan antara paritas dengan premature $p$ value $(0,005>0,05)$. Diharapkan tenaga kesehatan lebih memberikan perhatian pada ibu dengan paritas tinggi Karena dapat meningkatkan kejadian BBLR dan premature.
\end{abstract}

Kata Kunci $\quad$ : Paritas, BBLR, Prematur

\begin{abstract}
Parity is a factor that greatly influences the conception result. High parity will have an impact on the emergence of various health problems for both mothers and babies born. Parity affects infant outcome, including the incidence of affixia, Low Birth Weight and preterm. This study aims to determine the relationship between parity and infant outcomes at Muhammadiyah Palembang Hospital, namely Low Birth Weight and premature. This research is a descriptive analytic type with a retrospective design on 336 samples. The population in this study were all newborns recorded in hospital medical records, the study sample was 336. The study analysis used chi square analysis. The results showed that there was a relationship between parity and Low Birth Weight $p$ value $(0.006>0.05)$ and there was a relationship between parity and premature $p$ value (0.005>0.05). It is hoped that health workers will pay more attention to mothers with high parity because it can increase the incidence of Low Birth Weight and premature.
\end{abstract}

Keywords: Parity, Low Birth Weight, Premature 


\section{PENDAHULUAN}

Bayi Baru Lahir (BBL) merupakan bayi yang baru dilahirkan dengan usia kehamilan atau masa gestasinya dinyatakan cukup bulan (aterm) yaitu 36-40 minggu (Mintayani, 2010). Periode neonatal yang berlangsung sejak bayi lahir sampai usianya 28 hari merupakan waktu yang berlangsung perubahan fisik yang dramatis pada bayi baru lahir (Adeselpi, 2017).

Secara global, sebesar 4,5 juta kematian bayi terjadi pada tahun 2015 atau 32 kematian per 1.000 kelahiran hidup. Di wilayah Asia sendiri, Asia Tenggara menduduki peringkat tiga tertinggi pada kematian bayi pada tahun 2015 setelah Asia Selatan (41 kematian per 1.000 kelahiran hidup) dan Asia Tengah (28 kematian per 1.000 kelahiran hidup), yaitu 22 per 1.000 kelahiran hidup. AKB di Indonesia dan Kamboja sendiri masih berada diatas AKB Asia Tenggara, yaitu masing-masing 23 per 1.000 kelahiran hidup dan 25 per 1.000 kelahiran hidup, sedangkan Filipina sudah sama dengan angka kematian bayi Asia Tenggara (22 kematian per 1.000 kelahiran hidup) (Fitri, 2017).

Berdasarkan Survey Demografi Kesehatan Indonesia (SDKI, 2017), Angka Kematian Neonatal di Indonesia sebesar 15 bayi per 1000 kelahiran hidup lebih rendah jika dibandingkan dengan hasil laporan SDKI tahun 2012 sebesar 19 bayi per 1000 kelahiran hidup. Sedangkan Angka Kematian Bayi (AKB) berdasrkan SDKI 2017 sebesar 24 bayi per 1000 kelahiran hidup turun jika dibandingkan dengan hasil SDKI 2012 sebesar 29 bayi per 1000 kelahiran hidup (Kemenkes, 2018).

Berdasarkan data Dinas Kesehatan Kota Palembang tahun 2018, berdasarkan laporan program anak, jumlah kematian bayi di tahun 2017 sebanyak 29 kasus kematian yang terdiri dari 20 bayi neonatus ( 0 - 28 hari) dan 9 bayi (29 - 11 bulan) dari 27.876 kelahiran hidup. Penyebab kematian antara lain adalah diare, pneumonia, Asfiksia, BBLR, kelainan kongenital, dan lainnya (Dinkes Kota Palembang, 2018).
Penyebab kematian bayi ada dua macam yaitu endogen dan eksogen. Kematian bayi endogen atau kematian neonatal yang disebabkan oleh faktor-faktor anak yang dibawa sejak lahir, diperoleh dari orang tuanya pada saat konsepsi. Kematian bayi endogen juga disebabkan dari kondisi bayinya sendiri yaitu berat badan lahir rendah, bayi prematur, dan kelainan kongenital. Sedangkan kematian bayi eksogen atau kematian post-neonatal disebabkan oleh faktor-faktor yang berkaitan dengan pengaruh lingkungan luar (Lestari, 2018).

Bayi Baru Lahir memiliki resiko ganggguan kesehatan paling tinggi, berbagai masalah kesehatan bias muncul. Sehingga tanpa penanganan yang tepat, biasa berakibat fatal. Komplikasi Neonatal yang menjadi penyebab kematian terbanyak yaitu asfiksia, bayi berat lahir rendah dan infeksi. Komplikasi ini sebenarnya dapat segera dicegah dan ditangani, namun terkendala oleh akses kepelayanan kesehatan, kemampuan tenaga kesehatan, keadaan ekonomi, system rujukan yang belum berjalan dengan baik, terlambatnya detekeksi dini, dan kesadaran orangtua untuk mencari pertolongan (Kemenkes RI, 2015).

Paritas adalah banyaknya kelahiran hidup yang dipunyai oleh seorang wanita. Paritas merupakan faktor yang sangat berpengaruh terhadap hasil konsepsi. Uterus yang telah melahirkan banyak anak cenderung tidak efisiens dalam semua kala persalinan. Hal ini karena uterus telah mengalami perubahan dalam keelastisannya. Ibu yang pernah hamil atau melahirkan anak empat kali atau lebih, kemungkinan akan banyak ditemui keadaan antara lain kesehatan terganggu, anemia, kurang gizi, kekendoran pada dinding perut dan dinding rahim, dan tampak ibu dengan perut menggantung. Kehamilan lebih dari empat anak dengan jarak kurang dari dua tahun dapat mengakibatkan antara lain berat badan lahir rendah, nutrisi kurang, waktu/lama, menyusui berkurang, kompetensi dalam sumber-sumber keluarga, lebih sering terkena penyakit, tumbuh kembang lebih 
lambat, dan pendidikan/intelegensia dan pendidik anak ademis lebih rendah (Lestari, 2017).

Persalinan preterm lebih sering terjadi pada kehamilan pertama. Kejadiannya akan berkurang dengan meningkatnya jumlah paritas yang cukup bulan sampai dengan paritas keempat. Pada paritas 1 atau primigravida resiko ibu mengalami komplikasi preeklampsia dan eklampsia lebih tinggi, sedangkan preeklampsiaeklampsia merupakan salah satu komplikasi kehamilan yang berdampak pada morbiditas dan mortalitas dari ibu maupun bayi yang yang akan dilahirkan. Komplikasi yang dialami oleh ibu seperti preeklampsia maupun eklampsia cenderung menyebabkan kehamilan harus diterminasi sehingga meningkatkan risiko untuk terjadinya persalinan preterm (Wahyuni, 2017).

Berdasarkan data yang didapat dari Rumah Sakit Muhammadiyah Palembang, jumlah kejadian BBLR dan premature di RS Muhammadiyah Palembang di tiga tahun terakhir adalah 3,6\% menjadi $2,3 \%$ dan mengalami peningkatan menjadi $9,6 \%$.

Berdasarkan latar belakang diatas peneliti tertarik untuk melakukan penelitian dengan judul "Pengaruh Paritas Terhadap BBLR dan Prematur Di Rumah Sakit Muhammadiyah Palembang Tahun 2019".

\section{METODE PENELITIAN}

\section{Ruang Lingkup Penelitian}

Penelitian ini termasuk dalam ruang lingkup mata kuliah kegawatdaruratan neonatal. Penelitian ini dilakukan pada semua ibu bersalin normal untuk melihat hasil luran janin berdasarkan paritas ibu di Rumah Sakit Muhammadiyah Palembang tahun 2019 untuk mengetahui pengaruh BBLR dan prematur.

\section{Desain Penelitian}

Penelitian ini menggunakan metode analitik dengan pendekatan case control.

\section{Waktu Penelitian}

Penelitian ini dilakukan di bulan November 2020.

\section{Tempat Penelitian}

Penelitian ini akan dilaksanakan di Rumah Sakit Muhammadiyah Palembang.

\section{Jenis Data}

Penelitian ini menggunakan data sekunder, yaitu didapat dari data Medical Record Rumah Sakit Muhammadiyah Palembang tahun 2019 meliputi paritas ibu, hasil luaran janin (BBLR, prematur). Pengumpulan data pada penelitian ini menggunakan check list.

\section{Populasi dan Sampel}

Populasi pada penelitian ini adalah semua bayi baru lahir yang tercatat di rekam medic Rumah Sakit Muhammadiyah Palembang tahun 2019. Sampel dalam penelitian ini adalah kelompok kasus dan kontrol. Kelompok kasus adalah bayi baru lahir beresiko yang tercatat data di Rekam Medik RS serta memiliki kelengkapan data yang dibutuhkan. Sedangkan kelompok control adalah bayi baru lahir normal yang tercatat di Rekam Medik di RS dan memiliki kelengkapan data yang dibutuhkan dan diseleksi secara random sampling.

$$
\text { Sampel penelitian diambil }
$$
menggunakan rumus sehingga berjumlah 336 orang. Pada penelitian ini kelompok kasus banding kelompok control yaitu $1: 1$, jumlah sampel pada kelompok kasus sebanyak 168 bayi (bayi BBLR dan prematur) dan kelompok control sebanyak 168 bayi (bayi baru lahir normal) jadi besar sampel pada penelitian ini diambil sebanyak 336 orang. Teknik pengambilan sampel ini dilakukan dengan cara pengambilan sampel secara acak sistematis yaitu menggunakan nilai interval 6.

\section{Teknik Analisis Data Analisa Data Univariat}

Analisa univariat dilakukan terhadap tiap variable dari hasil penelitian yaitu variable independen (paritas) dan variable dependen (hasil luaran janin yaitu asfiksia, BBLR dan prematur) yang dianalisis dengan menggunakan table distribusi frekuensi. 


\section{Analisa Bivariat}

Analisa bivariat adalah analisa data untuk mengetahui hubungan antara variable independen (paritas resiko tinggi dan paritas resiko rendah) dengan variable dependen (hasil luaran janin yaitu asfiksia, BBLR dan prematur) yang dianalisis dengan uji chisquare $\left(\mathrm{x}^{2}\right)$ dengan taraf signifikan $(\alpha)=0,05$.

\section{HASIL PENELITIAN}

Analisis Univariat

Paritas

Tabel 1.

Distribusi Frekuensi Berdasarkan Paritas di RS Muhammadiyah Palembang Tahun 2019

\begin{tabular}{cccc}
\hline No & Paritas & Frekuensi & $\%$ \\
\hline 1 & Tinggi & 229 & 68,2 \\
\hline 2 & Rendah & 107 & 31,8 \\
\hline & Total & 336 & 100 \\
\hline
\end{tabular}

Dari tabel 1 dapat di lihat bahwa distribusi frekuensi dari 336 responden yang mengalami paritas tinggi sebesar $68,2 \%$ dan paritas rendah hanya $31,8 \%$.

\section{BBLR}

\section{Tabel 2.}

Distribusi Frekuensi Berdasarkan BBLR di RS Muhammadiyah Palembang Tahun 2019

\begin{tabular}{cccc}
\hline No & BBLR & Frekuensi & $\%$ \\
\hline 1 & Ya & 105 & 31,3 \\
\hline 2 & Tidak & 231 & 68,8 \\
\hline & Total & 336 & 100 \\
\hline
\end{tabular}

Dari table 2. dapat di lihat bahwa distribusi frekuensi 336 responden yang mengalami BBLR sebesar 32,3\% dan yang tidak mengalami BBLR sebesar $68,8 \%$.

\section{Prematur}

Tabel 3.

Distribusi Frekuensi kejadian Prematur di RS Muhammadiyah Palembang

Tahun 2019

\begin{tabular}{cccc}
\hline No & Prematur & Frekuensi & $\%$ \\
\hline 1 & Ya & 88 & 26,2 \\
\hline 2 & Tidak & 248 & 73,8 \\
\hline & & 336 & 100 \\
\hline
\end{tabular}

Dari table 3. dapat di lihat bahwa distribusi frekuensi 336 responden yang mengalami premature sebesar $26,2 \%$ dan yang tidak mengalami premature sebesar $73,8 \%$.

\section{Analisa Bivariat}

\section{Hubungan Antara Paritas Dengan Kejadian BBLR}

Tabel 4.

Hubungan paritas dengan BBLR di RS Muhammadiyah Palembang

\begin{tabular}{|c|c|c|c|c|c|c|c|}
\hline \multirow[t]{3}{*}{ Paritas } & \multicolumn{4}{|c|}{ BBLR } & \multirow{2}{*}{\multicolumn{2}{|c|}{ Jumlah }} & \multirow{3}{*}{$\begin{array}{l}P \\
\text { value }\end{array}$} \\
\hline & \multicolumn{2}{|c|}{$\mathrm{Ya}$} & \multicolumn{2}{|c|}{ Tidak } & & & \\
\hline & $\mathrm{n}$ & $\%$ & $\mathrm{n}$ & $\%$ & $\mathrm{~N}$ & $\%$ & \\
\hline Tinggi & 83 & 79 & 146 & 63,3 & 229 & 68,1 & 0,00 \\
\hline Rendah & 22 & 21 & 85 & 36,7 & 107 & 31,2 & 6 \\
\hline Jumlah & 105 & 100 & 231 & 100 & 336 & 100 & \\
\hline
\end{tabular}

Berdasarkan tabel 4. di atas dapat di lihat bahwa dari 105 responden yang mengalami BBLR terdapat $79 \%$ dengan paritas tinggi, sedangkan dari 231 responden yang tidak BBLR, terdapat $36,7 \%$ dengan paritas rendah.

Dari hasil uji Chi-Square di dapatkan nilai $p$ value $0,006(<\alpha 0,05)$, hal ini menunjukan ada hubungan antara paritas dengan kejadian BBLR. 


\section{Hubungan Antara Paritas Dengan Kejadian Prematur}

Tabel 5.

Hubungan Antara Paritas dengan

Prematur di RS Muhammadiyah Palembang Tahun 2019

\begin{tabular}{lccccccc}
\hline \multirow{2}{*}{ Paritas } & \multicolumn{4}{c}{ Kejadianprematur } & Jumlah & P value \\
\cline { 2 - 5 } & \multicolumn{3}{c}{ Ya } & \multicolumn{2}{c}{ Tidak } & & \\
\cline { 2 - 6 } & $\mathrm{n}$ & $\%$ & $\mathrm{n}$ & $\%$ & $\mathrm{~N}$ & $\%$ & \\
\hline Tinggi & 71 & 80,6 & 158 & 63,8 & 229 & 68,2 & 0,005 \\
\hline Rendah & 17 & 19,4 & 90 & 36,2 & 107 & 31,8 & \\
\hline Jumlah & 88 & 100 & 248 & 100 & 336 & 100 & \\
\hline
\end{tabular}

Berdasarkan tabel 5 di atas dapat di lihat bahwa dari 88 responden yang mengalami premature terdapat $80,6 \%$ dengan paritas tinggi, sedangkan dari 248 responden yang tidak prematur, terdapat $36,2 \%$ dengan paritas rendah.

Dari hasil uji Chi-Square di dapatkan nilai $p$ value $0,005(<\alpha 0,05)$, hal ini menunjukan bahwa ada hubungan antara paritas dengan kejadian premature.

\section{Pembahasan}

Paritas adalah kelahiran setelah gestasi 20 minggu tanpa memperhatikan apakah bayi hidup atau mati. Paritas ibu merupakan frekuensi ibu pernah melahirkan anak hidup atau mati, tetapi bukan aborsi.

Hasil penelitian menunjukkan sebagian besar paritas tinggi $68,2 \%$, tidak BBLR $68,8 \%$ dan tidak premature $73,8 \%$.

Paritas yang tinggi akan berdampak pada timbulnya berbagai masalah kesehatan baik bagi ibu maupun bayi yang dilahirkan. Kehamilan dan persalinan yang berulangulang menyebabkan kerusakan pembuluh darah di dinding Rahim dan kemunduran daya lentur (elastisitas) jaringan yang sudah berulang kali diregangkan saat kehamilan sehingga cenderung timbul kelainan letak ataupun kelainan pertumbuhan plasenta dan pertumbuhan janin sehingga melahirkan BBLR (Nurseha, 2017).

Hasil analisis penelitian menunjukkan sebagian besar bayi BBLR adalah dari ibu paritas tinggi (79\%) dan ada hubungan antara paritas dengan kejadian BBLR. Ini sejalan dengan hasil penelitian Zaenab (2006), yaitu ibu yang pernah melahirkan anak lebih dari tiga kali berisiko melahirkan bayi BBLR, ibu dengan paritas $>3$ anak akan berisiko 2 kali melahirkan BBLR. Penelitian ini juga sejalan dengan penelitian Ernawati (2013) mengenai hubungan factor umur dan paritas ibu dengan kejadian bayi berat lahir rendah di Rumah Sakit Umum PKU Muhammadiyah Bantul. Hasil analisis di dapatkan nilai p-value sebesar 0,01 yang berarti terdapat hubungan yang berarti terdapat hubungan yang bermakna antara paritas dengan kejadian BBLR.

Dalam Wiknjosastro (2017), uterus yang telah melahirkan banyak anak cenderung tidak efisien dalam semua kala persalinan. Hal ini karena uterus telah mengalami perubahan dalam keelastisannya. Salah satu komplikasi yang dapat muncul akibat kehamilan lebih dari empat anak yaitu BBLR, ini disebabkan terganggunya uterus terutama dalam hal fungsi pembuluh darah yang dapat mempengaruhi nutrisi kejanin sehingga menyebabkan gangguan pertumbuhan.

Hasil analisis penelitian menunjukkan sebagian besar bayi premature adalah dari ibu paritas tinggi $(80,6 \%)$ dan ada hubungan antara paritas dengan kejadian prematur. Ini sesuai dengan teori yang dikemukakan Saifudin (2017) menyatakan bahwa wanita yang pernah melahirkan lebih dari 1 kali atau yang termasuk dalam paritas tinggi (multipara dan grandemultipara) mempunyai resiko lebih tinggi mengalami persalinan premature karena menurunnya fungsi alat alat reproduksi dan meningkat pula resiko terjadinya perdarahan anterpartum, paritas tinggi berkaitan erat dengan penambahan usia ibu melahirkan.

Hasil penelitian ini tidak sejalan dengan penelitian yang di lakukan Khoiriyah (2017) yang berjudul hubungan paritas dengan kejadian BBLR di RSUD Abdul Moloek Tahun 2017. Hasil penelitian dengan hasil uji statistic menggunakan chi square di dapatkan $p$ value $0,628>\alpha 0,05$, artinya tidak terdapat hubungan antara paritas ibu dengan 
kejadian BBLR di RSUD Abdul Moeloek Tahun 2017.

Paritas $>4$ menyebabkan rahim mengalami kontraksi yang berlebihan dan fisiologi rahim yang kurang optimal untuk pertumbuhan janin (Faser, 2013).

\section{SIMPULAN DAN SARAN}

\section{Simpulan}

1. Dari 336 responden sebagian besar yang mengalami kejadian paritas tinggi $68,1 \%$, tidak BBLR $68,8 \%$ dan tidak premature $73,8 \%$.

2. Ada hubungan antara paritas dengan kejadian BBL di Rumah Sakit Muhammadiyah Palembang ( $p$ value 0,006 ).

3. Ada hubungan antara paritas dengan kejadian premature ( $p$ value 0,005 )

\section{Saran}

Diharapkan tenaga kesehatan dapat memberikan perhatian lebih pada ibu dengan paritas tinggi karena dapat meningkatkan angka kejadian BBLR dan premature.

Paritas tinggi merupakan paritas rawan karena banyak kejadian obstetric patologi yang bersumber pada paritas tinggi. Rahim akan menjadi semakin lemah karena jaringan parut uterus akibat kehamilan berulang. Jaringan parut ini menyebabkan tidak adekuatnya persediaan darah keplasenta, sehingga plasenta tidak mendapat aliran darah yang cukup untuk menyalurkan nutrisi kejanin akibatnya pertumbuhan janin terganggu (Ningrum, 2017).

\section{DAFTAR PUSTAKA}

Adeselpi. 2017. Perbandingan Hasil Penilaian Awal Bayi Baru Lahir Antara Ibu Bersalin Yang Dilakukan Dan Tidak Dilakukan Hipnosis Di Wilayah Kerja Puskesmas Indihiang Kota Tasikmalaya Tahun 2017

Ernawati. 2017. Hubungan Faktor Umur Ibu Dan Paritas Dengan Kejadian Bayi Berat Lahir Rendah Di Rumah Sakit Umum Pku Muhammdiyah Bantul Tahun 2016
Kemenkes RI. 2015. Profil Kesehatan Indonesia tahun 2016. http://www.kemenkes.go.id, diakses 20 Oktober 2019

Lestari. 2017. Perbedaan Hasil Luaran Bayi Antara Ibu Paritas Tinggi Dan Ibu Paritas Rendah

Ningrum, N. W. et al. 2017. Hubungan Umur, Paritas Dan Kejadian Anemia Dengan Kejadian Persalinan Prematur Di Rsud Dr. H. Moch. Ansari Saleh Banjarmasin Tahun 2016.

Nurseha, Annisa Zahara Berlannov. Faktorfaktor yang berhubungan dengan Kejadian BBLR. Falatehan Health Journal, 4 (5) (2017). ISSN 2088673XJ Health.4

Saifuddin. 2017. Ilmu Kebidanan. Jakarta : PT. Sarwono Prawirohardjo.

Wiknjosastro. 2007. Ilmu Kebidanan Edisi Ketiga Cetakan Ketujuh. Jakarta, YBPSP..

Zaenab. 2006. Beberapa Faktor Risiko Kejadian BBLR di Rumah Sakit Al Fatah Ambon Periode JanuariDesember. SKripsi. RS Al-Fatah Ambon. 
